\title{
NX CAM Post Processing Errors: Machine Data File Generator vs. Post Builder
}

\section{Srđan Živković}

Head of Section Military Technical Institute Belgrade, Serbia Experimental Aerodynamics Division Prototype Production Department
Replacing or upgrading software packages requires a detailed analysis and testing.This is especially important for software modules that are part of the production process. Machining of free-form surfaces always requires using of a five-axis milling machine. Tool path post-processing for these machines allways attracts special attention. The most important part of the postprocessor is implemented IKS (Inverse Kinematic Solver). Implemented IKS in the postprocessor must accurately describe the kinematics of milling machine in the production plant. Military Technical Institute performed parallel testing of two postprocessing modules of CAD/CAM system Siemens PLM NX: and old GPM (Graphics Postprocessor Module and a new module MOM (Manufacturing Output Manager). Complete analysis was sent to the NX support center and application engineers confirmed that the old and new postprocessors do not behave identically. The paper describes in detail the analysis and explains the solution of the presented problem.

Keywords: Five-Axis Milling, Post processing, CAD/CAM

\section{INTRODUCTION}

Any replacement of software, especially that on which directly depend on the flow and quality of the production process requires a detailed analysis and testing. In the manufacturing process there is no "Undo" command. Errors produced on the machined parts will inevitably lead to the re-manufacturing work. It is clear that in such cases costs are multiplied.

The new version of Siemens PLM NX, starting from NX8, completely abandoned the concept of GPM post processing, which has been in operation for more than 20 years.

GPM (Graphics Postprocessor Module) is replaced by a new, improved, MOM (Manufacturing Output Manager) module, which is based on the TCL (Tool Command Language) programming language.

Post-processing of tool path for five-axis milling machines, generated by the CAD/CAM system is a critical activity in engineering work. Kinematic model, implemented in the postprocessor must accurately describe the kinematics of milling machine in the production plant.

Software upgrades or new modules must provide the continuity of the production process. It is expected that for the same settings MOM module generates identical machining program as the old GPM module, whose validity was confirmed in multiannual production.

The above reasons explain why such testing is necessary before a complete transition to the new

Received: September 2014, Accepted: September 2015

Correspondence to: Dr Srdjan Živković, Mech.Eng.

Military Technical Institute Belgrade,

Ratka Resanovića 1, 11030 Belgrade, Serbia

E-mail: srdjan.vti@gmail.com

doi:10.5937/fmet1602159Z

(C) Faculty of Mechanical Engineering, Belgrade. All rights reserved software in everyday engineering work.

Such a comparative analysis is made in the MTI (Military Technical Institute). It was concluded that for the same settings GPM and MOM do not generate the same output NC (Numerical Control) code. It is concluded that there are differences in the applied kinematic model in GPM and MOM modules for five axis milling machines with dual rotary heads.

Siemens NX product support application engineers confirmed all the allegations MTI.

\section{FIVE-AXIS MILLING MACHINES}

Five-axis milling machines are classified according to the combination of linear $(\mathrm{T})$ and rotary $(\mathrm{R})$ axes. Even though a large number of possible combinations, in practice five-axis milling machining are reduced to three different types [1]:

1. RRTTT: Dual rotary tables type 5-axis machine

2. TTTRR: Dual rotary heads type 5-axis machine

3. RTTTR: Rotary Table and Head 5-axis machine

For the five-axis milling of the second type (TTTRR), the analysis was performed by generating NC code with two different post processing module.

\subsection{Dual Rotary Heads type 5-Axis Milling Machine}

The 5-axis milling machine STARRAG NTV 225 is shown in figure 1 . It is a five-axis milling machine of the second type (TTTRR) with three linear $(\mathrm{X}, \mathrm{Y}, \mathrm{Z})$ and two rotary axes $(\mathrm{A}, \mathrm{B})$ of the following technical characteristics:

- X-Axis: $1870 \mathrm{~mm}$

- Y-Axis: $900 \mathrm{~mm}$

- Z-Axis: $850 \mathrm{~mm}$

- A-Axis: $\pm 20^{\circ}$, plane of rotation: $\mathrm{YZ}$ 
- B-Axis: $\pm 20^{\circ}$, plane of rotation: $\mathrm{XZ}$

- Pivot distance: varying in the range of 370 to 470 $\mathrm{mm}$; manually adjustable pulling in/out of main spindle.

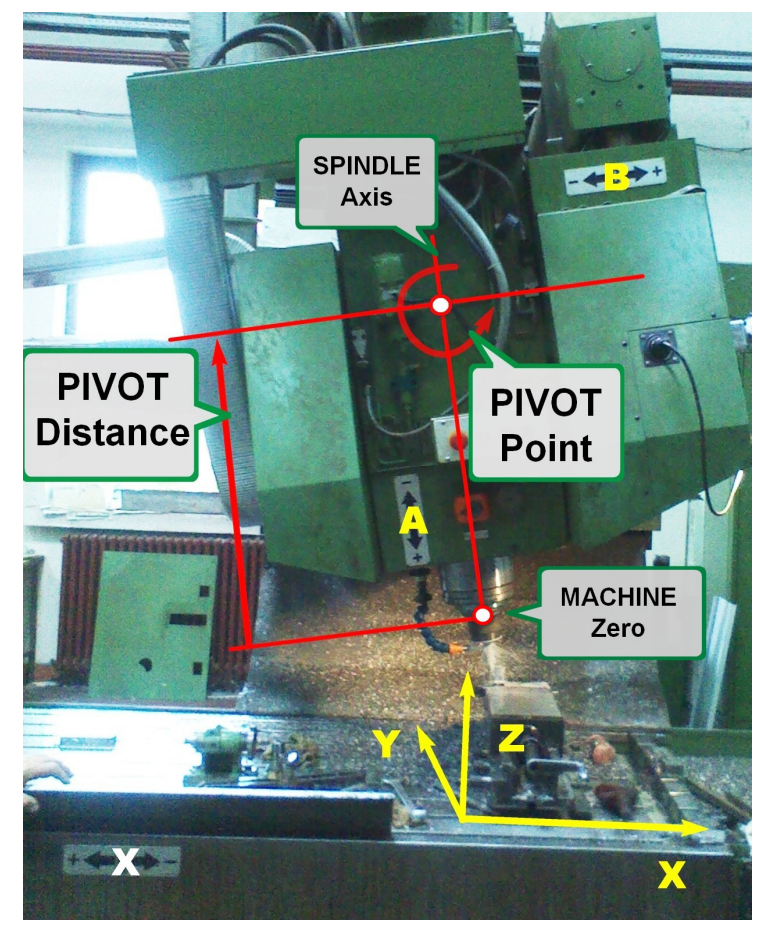

Figure 1. TTTRR - Starrag NTV 225

The control unit of the machine is Allen Bradley OSAI 8600 CNC [2]. NC control unit is connected via DNC (Distributed Numerical Control) connection with a host computer. This connection is realized through a serial RS-232 interface.

Setting pivot distance on the five-axis machine tools is the most critical phase in the whole, otherwise a very complicated procedure milling complex spatial forms. Most of the errors occur at this stage. That is why setting the pivot distance requires special attention. Adjustment procedure is described in detail in the next chapter.

\subsection{Pivot distance measurement procedure}

In figure 1 are indicated the key elements for the pivot distance measurement: machine zero, pivot point and axis of the spindle.

In order to obtain accurate machining, it is necessary that the distance from the tool tip to the pivot point of the machine is exactly the same as the value defined in the postprocessor.

Pivot distance (pivot length) measurement procedures are explained in the book [3] and webinar [4] cannot be applied to all five-axis machines with double rotating head. In cases where the five axis milling machine does not have the technical capabilities to rotate the spindle for 90 degrees, such as the case with the five axis milling machine in figure 1 , these procedures are not usable.

Pivot distance measurement procedure presented in [5] is applicable to all five-axis milling machines with dual rotating head. This procedure is more general; procedures presented in the [3] and [4] are just a special case of the procedure presented in the [5].

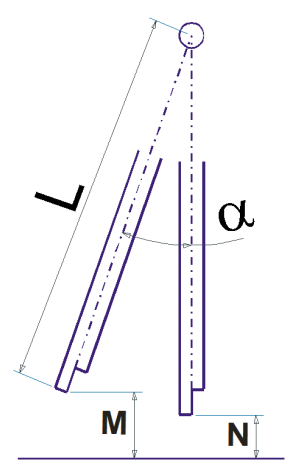

Figure 2. Pivot distance measurement

Pivot distance measurement procedure requires cylindrical mandrel, which is the top cut off exactly halfway (maximum diameter), figure 2.

- First, the spindle of the machine is placed in a vertical position $(\mathrm{A}=0$ and $\mathrm{B}=0)$.

- Second, measure the distance from the working table to the top of the mandrel. In figure 2 this distance is marked as "N".

- Third, the machine spindle (axis A or B, anyway) is rotated for a known angle, for example $20^{\circ}$. In Figure 2 this angle is marked by " $\boldsymbol{\alpha}$ ".

- Fourth, measure the distance from the edge of the rotated mandrel to the working table. In the figure 2 this distance is marked with "M".

The distance of pivot point (pivot length), in figure 2 denoted as "L", is calculated from the eq. (1).

$$
L=(M-N) /(1-\cos \alpha)
$$

If the angle of rotation is 90 degrees, the obtained equations are presented in the [3] and [4]. Calculated pivot distance is compared with the value defined in the postprocessor. If necessary, the spindle (manually by handle) pull-out or retract to obtain a distance defined by the postprocessor, figure 3 .

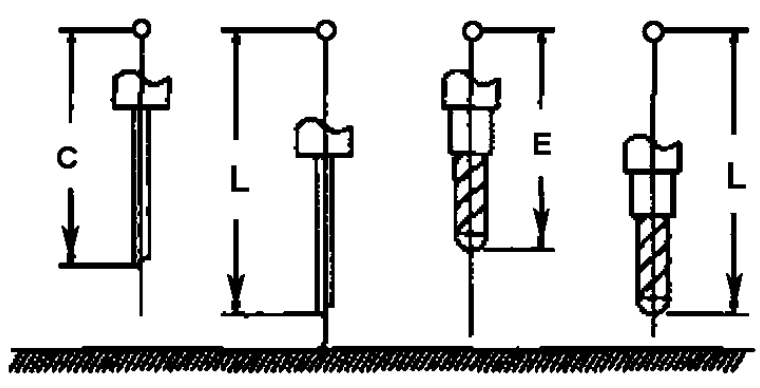

Figure 3. Different lengths of the cutting tool relative to the pivot point; Pivot distance adjustment.

Auxiliary cylindrical mandrel is removed from the tool holders and in its place the cutting tool is put. Tool tip relative to the pivot point at an unknown distance, in figure 3 is marked as length " $E$ ". The spindle is pulled out or retracted so that the tool tip comes at the same position where it was previously cylindrical mandrel, in figure 3 marked as length "L".

After all the above steps, five-axis milling machine is ready for operation. For proper operation, it is necessary that the distance of the pivot is always accurately measured. 


\section{GPM AND MOM POSTPROCESSORS}

Next, a very sensitive step is post-processing the generated tool path for the appropriate combination of machine tool and its control unit. Postprocessor is a software product which translates the input APT (Automated Programming Tool) code in the NC machining program.

CAM module generates source code with the appropriate data, and for the five-axis machining processing has the following form:

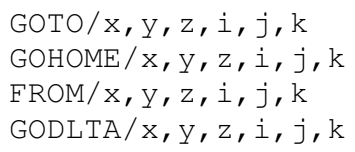

The first three numbers are the position vector of the tool tip $(x, y, z)$, the last three are components of the vector axis of the cutting tool $(\mathrm{i}, \mathrm{j}, \mathrm{k})$. Based on the kinematic model defined in the postprocessor, the generated tool path is transformed into movement commands of five axis milling machine for three linear axes $(\mathrm{X}, \mathrm{Y}, \mathrm{Z})$ and two rotational $(\mathrm{A}, \mathrm{B})$.

\subsection{Siemens NX GPM postprocessor}

GPM postprocessor (CAD/CAM system Siemens NX formerly Unigraphics), was developed in the $80^{\mathrm{s}}$ and $90^{\mathrm{s}}$ of the last century, according to the needs and requirements of ISO 6983 standard. Starting from the source code of the tool path CLS (Cutter Location Source) through intermediate steps BCL (Binary Cutter Location) post-processing gives a final $\mathrm{NC}$ machining program.

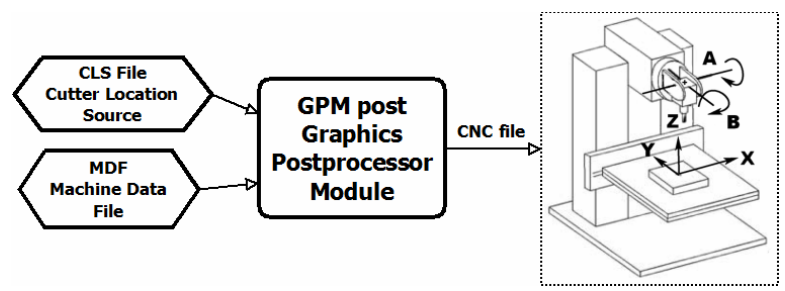

Figure 4. CLS file is post processed according to MDF instructions

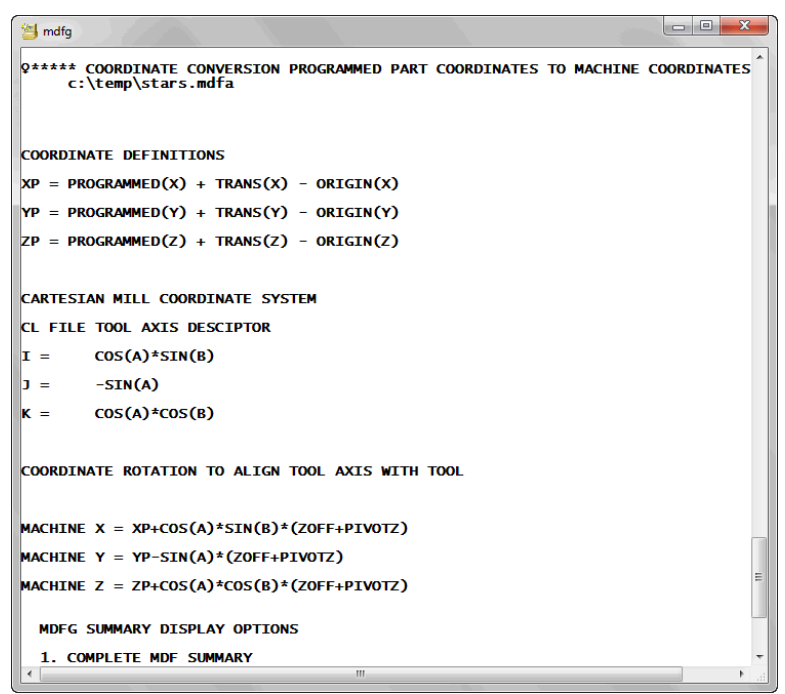

Figure 5. Machine Data File Generator: Postprocessor summary listing; 5-Axis milling machine; Tool path coordinate transformation.
Figure 4 shows these steps [6]. The main drawback of this concept is the multiplication of files on the same tool path.

MDF (Machine Data File) contains a detailed description of the machine tool and its control unit. Machine Data are defined using a special generator MDFG (Machine Data File Generator). MDFG module provides a summary listing of the generated postprocessor for a specific machine tool. Figure 5 shows a portion of the MDF listing, which shows the equations of conversion programmed part coordinates to machine coordinates for five-axis milling machine with dual rotating head. Users are not able to change the equation of kinematic transformations.

\subsection{Siemens NX MOM postprocessor}

GPM post processing module was replaced by a new, improved, module MOM (Manufacturing Output Manager). Both modules existed in parallel, including version NX7.

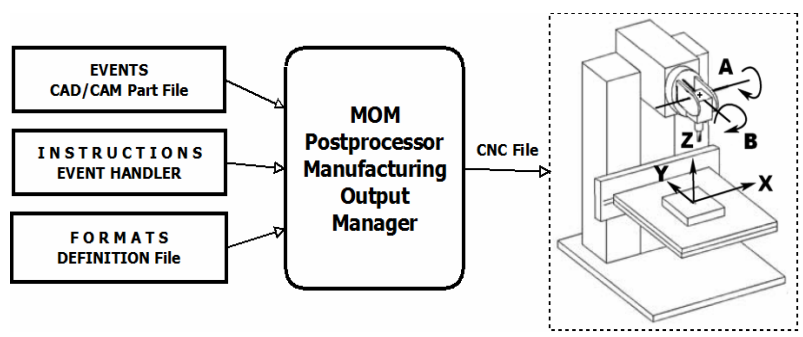

Figure 6. MOM post processing procedure

Similar to the concept of GPM, MOM module requires several components [6], shown in figure 6:

- Events Generator is the basic module on the CAD/CAM system level.

- Event Handler is a file that contains a set of instructions that determine how each of the events is to be processed.

- Definition File contains static information about a specific combination of machine tool control unit.

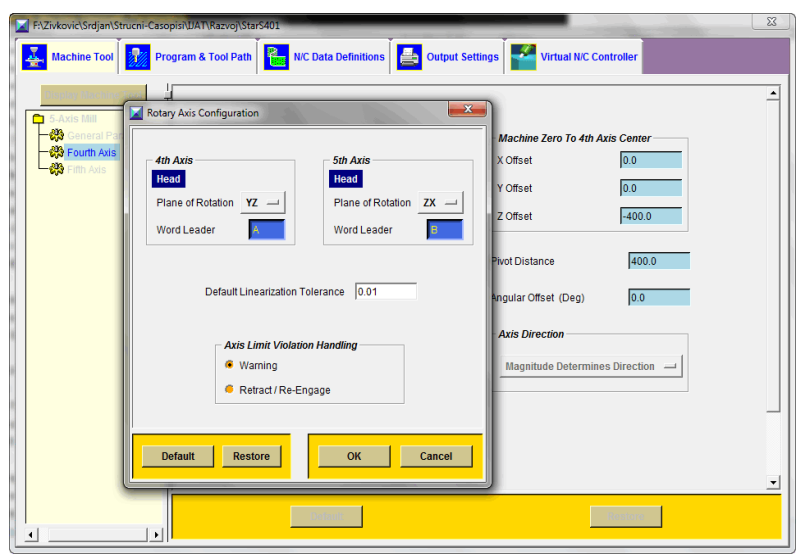

Figure 7. Post Builder module: Rotary Axis settings; 5-Axis milling machine, Dual Rotary Heads

Tool path is post processed using instructions from the Event Handler and the formats in the Definition File. Users can use Post Builder (PB) module to create a postprocessor for its own needs [7].

Figure 7 shows the settings of the rotary axis in PB module for five-axis milling machine shown in figure 1 . 


\section{POSTPROCESSORS TESTING}

For testing purposes, using the PB module generated postprocessor with identical setting such as the postprocessor generated using MDFG module. For the machine shown in figure 1 , the five-axes milling machine with dual rotating head, set the following kinematic parameters:

- Three linear axes: X,Y,Z

- Fourth Axis (Head)

o Plane of rotation: YZ

○ Word leader: A

$\circ$ Axis limits: $\pm 20^{\circ}$

- Fifth Axis (Head)

o Plane of rotation: XZ

○ Word leader: B

$\circ$ Axis limits: $\pm 20^{\circ}$

- Machine Zero to $4^{\text {th }}$ axis center:

$\circ$ X Offset: $0 \mathrm{~mm}$

○ Y Offset: $0 \mathrm{~mm}$

o Z Offset: $-400 \mathrm{~mm}$

o Angular Offset: $0^{\circ}$

o Pivot Distance: $400 \mathrm{~mm}$

- $4^{\text {th }}$ Axis Center to $5^{\text {th }}$ Axis Center:

$\circ$ X Offset: $0 \mathrm{~mm}$

$\circ$ Y Offset: $0 \mathrm{~mm}$

$\circ$ Z Offset: $0 \mathrm{~mm}$

o Angular Offset: $0^{\circ}$

o Pivot Distance: 400mm

After generating the tool path in version NX6, it is post processed using GPM and MOM postprocessor. Figure 8 shows the path: variable axis contouring, tool axis normal to part, end-mill cutter diameter $14 \mathrm{~mm}$, corner radius $0 \mathrm{~mm}$. Machining part is the fourth of the torus. The start and end position of the cutting tool is vertical.

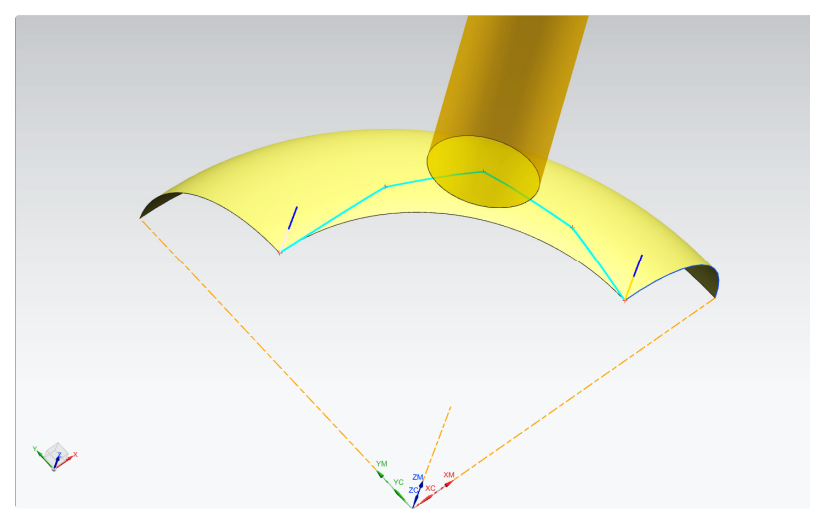

Figure 8. Variable axes tool path prepared for postprocessor testing

Table 1: Cutter Location Source Code, generated tool path

\begin{tabular}{|c|c|c|c|c|}
\hline \multirow{2}{*}{} & \multicolumn{4}{|c|}{ Tool Path: CLS } \\
\cline { 2 - 5 } & $\mathrm{N} 15$ & $\mathrm{~N} 20$ & $\mathrm{~N} 30$ & $\mathrm{~N} 40$ \\
\hline $\mathrm{x}$ & 30.0000 & 31.1750 & 29.4556 & 21.4447 \\
\hline $\mathrm{y}$ & 0.0000 & 7.2502 & 21.8737 & 27.4694 \\
\hline z & 25.8000 & 19.9040 & 18.8535 & 19.4085 \\
\hline $\mathrm{i}$ & 0.00000 & 0.09771 & 0.26845 & 0.14915 \\
\hline $\mathrm{j}$ & 0.00000 & 0.02273 & 0.19935 & 0.19106 \\
\hline $\mathrm{k}$ & 1.00000 & 0.99496 & 0.94244 & 0.97018 \\
\hline
\end{tabular}

Tool path in figure 8 is quite short: there are exactly 40 lines with GOTO commands. For clarity, table 1 shows only 4 lines of tool path. It is enough to display the differences between GPM and MOM postprocessor. Rows (x, y, z, i, j, k) are parameters of GOTO commands. The columns are labeled as sequence number to compare the calculated NC coordinates.

\subsection{GPM post processing}

For post-processing tool path, in the GPM module was used postprocessor StarS.MDFA (the name is an abbreviation of Starrag Srdjan), which was generated 15 years ago using MDFG module. The validity of this postprocessor has been confirmed multiple times during a decade of its use. Milling machine in figure 1 is a key issue in the production of the model's for wind tunnel testing. All parts are manufactured at the five-axis milling machine going full control of the geometry in CMM (Coordinate Measuring Machine) [8].

Table 2 shows the NC program generated by GPM module for the CLS from Table 1. Rows are calculated coordinate for linear motion of five axes (X, Y, Z, A, B).

Table 2: NC code generated using GPM postprocessor

\begin{tabular}{|c|c|c|c|c|}
\hline \multirow{2}{*}{} & \multicolumn{4}{|c|}{ GPM: S T A R S . MDFA } \\
\cline { 2 - 5 } & $\mathrm{N} 15$ & $\mathrm{~N} 20$ & $\mathrm{~N} 30$ & $\mathrm{~N} 40$ \\
\hline $\mathrm{X}$ & 30.000 & 70.261 & 136.833 & 81.106 \\
\hline $\mathrm{Y}$ & 0.000 & 16.339 & 101.614 & 103.889 \\
\hline $\mathrm{Z}$ & 25.800 & 17.886 & -4.170 & 7.481 \\
\hline A & 0.000 & -1.302 & -11.499 & -11.014 \\
\hline B & 0.000 & 5.609 & 15.899 & 8.740 \\
\hline
\end{tabular}

\subsection{MOM post processing $-1^{\text {st }}$ settings}

The same tool path post-processed using NX/post module. Post-processor StarS401.PUI is generated by PB module. This post-processor has the identical settings as StarS.MDFA. These settings are listed at the beginning of this chapter. Table 3 shows the generated NC program.

Table 3: NC code generated using MOM postprocessor, $1^{\text {st }}$ settings

\begin{tabular}{|c|c|c|c|c|}
\hline \multirow{2}{*}{} & \multicolumn{4}{|c|}{ MOM: S T A R S 4 0 1 . PUI } \\
\cline { 2 - 5 } & $\mathrm{N} 15$ & $\mathrm{~N} 20$ & $\mathrm{~N} 30$ & $\mathrm{~N} 40$ \\
\hline $\mathrm{X}$ & 30,000 & 70,264 & 136,835 & 81,107 \\
\hline Y & 0,000 & 7,207 & 18,835 & 26,605 \\
\hline Z & 25,800 & 17,990 & 4,489 & 15,018 \\
\hline A & 0,000 & $-1,308$ & $-11,943$ & $-11,141$ \\
\hline B & 0,000 & 5,608 & 15,572 & 8,578 \\
\hline
\end{tabular}

It is obvious, that the $\mathrm{NC}$ program in table 3, completely different from the $\mathrm{NC}$ program in the table 2. It is clear that the applied equations of kinematic transformation for five axis milling machine with dual rotating head are not correct. They should be the same as the listing in figure 5 .

\subsection{MOM post processing $-2^{\text {nd }}$ settings}

To correct identified errors in the post-processor were replaced of axes. "B" axis is declared as a fourth axis and " $\mathrm{A}$ " as a fifth axis:

- Fourth Axis (Head) 
O Plane of rotation: $\mathrm{XZ}$

○ Word leader: B

- Fifth Axis (Head)

o Plane of rotation: YZ

o Word leader: A

Such a setting is not in accordance with the standard EIA RS-267 (Axis and Motion Nomenclature for Numerically Controlled Machines), but takes into account the independent and dependent rotational axes. Other settings are retained. Version of postprocessors with this setting named StarS402.PUI. Table 4 shows the generated NC program.

Table 4: NC code generated using MOM postprocessor, $2^{\text {nd }}$ settings

\begin{tabular}{|c|c|c|c|c|}
\hline \multirow{2}{*}{} & \multicolumn{4}{|c|}{ MOM: S T A R S 4 0 2 . PUI } \\
\cline { 2 - 5 } & $\mathrm{N} 15$ & $\mathrm{~N} 20$ & $\mathrm{~N} 30$ & $\mathrm{~N} 40$ \\
\hline $\mathrm{X}$ & 30.000 & 31.165 & 27.256 & 20.325 \\
\hline Y & 0.000 & 16.339 & 101.614 & 103.889 \\
\hline Z & 25.800 & 19.801 & 11.132 & 12.126 \\
\hline B & 0.000 & 5.609 & 15.899 & 8.740 \\
\hline A & 0.000 & -1.302 & -11.499 & -11.014 \\
\hline
\end{tabular}

Table 4 shows the correct coordinates for the axis of rotation obtained by the post-processing (axes A and B). Obtained are identical to the values in table 2 . When comparing the linear axis, shows that the only Y-axis correctly calculated, $\mathrm{X} \& \mathrm{Z}$ are not.

\subsection{MOM post processing - 3rd settings}

The third setting is changed only by the parameter "Machine Zero to 4th axis center":

$$
\begin{aligned}
& \circ \text { X Offset: } 0 \mathrm{~mm} \\
& \circ \text { Y Offset: } 0 \mathrm{~mm} \\
& \circ \text { Z Offset: } 0 \mathrm{~mm}
\end{aligned}
$$

Instead value minus $400 \mathrm{~mm}, \mathrm{Z}$ offset is set to $0 \mathrm{~mm}$. Version of postprocessors with this setting named StarS403.PUI. Table 5 shows the generated NC program.

Table 5: NC code generated using MOM postprocessor, $3^{\text {rd }}$ settings

\begin{tabular}{|c|c|c|c|c|}
\hline & \multicolumn{4}{|c|}{ MOM: S T A R S 4 0 3 . PUI } \\
\cline { 2 - 5 } & $\mathrm{N} 15$ & $\mathrm{~N} 20$ & $\mathrm{~N} 30$ & $\mathrm{~N} 40$ \\
\hline $\mathrm{X}$ & 30.000 & 70.261 & 136.833 & 81.106 \\
\hline $\mathrm{Y}$ & 0.000 & 16.339 & 101.614 & 103.889 \\
\hline $\mathrm{Z}$ & 425.800 & 417.886 & 395.830 & 407.481 \\
\hline B & 0.000 & 5.609 & 15.899 & 8.740 \\
\hline A & 0.000 & -1.302 & -11.499 & -11.014 \\
\hline
\end{tabular}

Table 5 shows the correct coordinates for the axis of rotation (axes A and B) and two linear (axes X and Y) obtained by the post-processing. Linear $\mathrm{Z}$ axis is still not correctly calculated but noted that the $400 \mathrm{~mm}$ greater than it should be.

This setting gave the closest results. $\mathrm{Z}$ coordinate value which is increased by $400 \mathrm{~mm}$ (there is such the value of $\mathrm{Z}$ offset for the machine of figure 1) cannot be corrected by setting inside the PB module. As shown in the previous settings, by entering an appropriate value for the $\mathrm{Z}$ offset of ,Machine Zero to $4^{\text {th }}$ axis center" gets totally incorrect NC program.

The final conclusion is that the equations of kinematic transformations for five-axis milling machining with dual rotating head inside MOM postprocessors are not correct.

\subsection{Solution of the problem}

The quickest and easiest solution of described problem is a modification custom command "before_motion". It is necessary a variable that refers to the $\mathrm{Z}$ axis reduce for the $\mathrm{Z}$ offset value of "Machine Zero to $4^{\text {th }}$ axis center". Listing of the Post Builder procedure is given below (TCL programming) [9]:

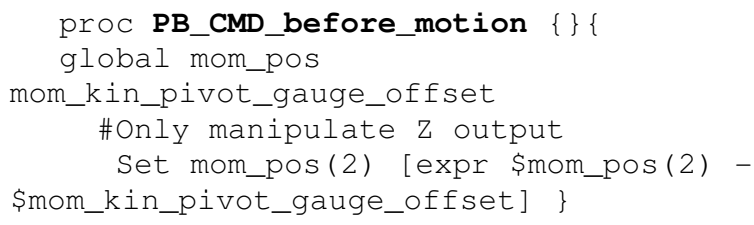

In addition, it is necessary to disable a new IKS (Inverse Kinematics Solver). Listing of the Post Builder procedure is given below:

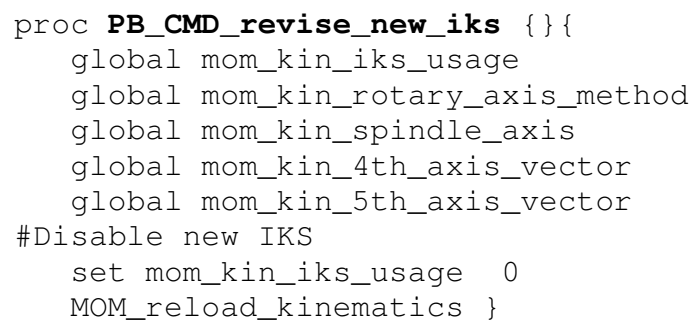

All other Post Builder settings must remain as described in section 4.4. After all specified settings and writing two procedures in the PB module, the generated $\mathrm{NC}$ program is correct. Just now, postprocessor for five axis milling machines with dual rotary heads generated using a PB module can be applied in everyday work without fear that machining parts will be defective.

\section{CONCLUSION}

All presented considerations have been transferred to NX product support engineers [10]. They confirmed that the PB and MDFG behave differently. The reason is as follows:

- In the Post Builder the offset is applied along the tool axis.

- In the Machine Data File Generator the offset is applied along the coordinate axes.

In their response explained [10]: "The reversal of $4^{\text {th }}$ $\& 5^{\text {th }}$ axes assignment is actually a bug with the early stage of NX/Post, where the old IKS (Inverse Kinematics Solver) was implemented incorrectly". There's no explanation as to whether this refers to the IKS within module MDFG.

It is obvious that the variables relating to "Machine Zero to $4^{\text {th }}$ axis center" and " 4 th $A x i s$ Center to $5^{\text {th }}$ Axis Center" are incorrectly implemented in IKS. It is shown by the analysis presented. All postprocessors at GTAC [10] have this variables are set equal zero. Clearly, they have not been tested with real values. If they did, the error would have been detected.

Unfortunately, none of the explained above is not in NX documentations. Inexperienced users cannot find a solution of described problem only by reading Post Builder documentation. 


\section{REFERENCES}

[1] Lee R. S., She C. H.: Developing a postprocessor for three types of five-axis machine tools, International Journal of Advanced Manufacturing Technology, vol. 13, pp. 658-665, 1997.

[2] Programming and Operator's manual, Allen Bradley OSAI series 8600, code: 45004102 Rel. B03 v3.3, Rockwell Automation, USA, edition 8/8/1986.

[3] Apro, K.: Secrets of 5-Axis Machining, Industrial Press Inc, New York USA, 2008.

[4] Bob-CAD support, Finding the Pivot Length for Head/Head 5-Axis Machines [Online], Available: http://bobcadsupport.com/lessons/5-axis-head-eadpivot-length/, [Accessed: Aug. 25, 2014.]

[5] Zivkovic, S.: Five-axis milling Technology of freeform surfaces (in Serbian: Tehnologija petoosnog glodanja složenih prostornih oblika), In Proceedings of $2^{\text {nd }}$ International Scientific Conference on defensive technologies OTEH, Military Technical Institute, Belgrade, 2007.

[6] Siemens NX8 Help [Online], Available: http://viewmold.com/sources/nx_8.0_help_library/\# uid:index, [Accessed: Avg. 25, 2014.]

[7] Magambo S., Ying L.: The NC Machining PostProcessing Technology Based on UG, International Journal of Science and Research (IJSR), Volume 2 Issue 9, pp. 131-134, 2013.

[8] Zivkovic, S.: Optimisations of Free Form Surfaces Measuring Using Coordinate Metrology Methods (in Serbian: Optimizacija merenja složenih prostornih oblika metodama koordinatne metrologije), Ph.D. thesis, Military Academy, Belgrade, 2011.

[9] TCL (Tool Command Language) Reference Manual [Online], Available: http://tmml. sourceforge. net/doc/tcl/, [Accessed: Sep. 2014.]

[10] GTAC (Global Technical Access Center) Siemens PLM Software Training and Support Services, [Online]. Available: https://support.industrysoftware. automation.siemens.com/gtac.shtml, [Accessed: Feb.
2014.] (correspodence by a representative of Siemens PLM for Serbia, „EuroCom“ Belgrade, www.eurocom.rs), feb. 2014.

\section{NOMENCLATURE}

$\mathrm{x}, \mathrm{y}, \mathrm{z} \quad$ Tool tip coordinates (CAD/CAM part)

$\mathrm{i}, \mathrm{j}, \mathrm{k} \quad$ Tool Axis vector (CAD/CAM part)

$\mathrm{X}, \mathrm{Y}, \mathrm{Z}$ Linear axes of milling machine

A,B Rotational axes of milling machine

N Sequence number

L Pivot distance

$\boldsymbol{\alpha} \quad$ Angle of inclination

$\mathrm{M}, \mathrm{N} \quad$ Distance from Working Table

\section{ГРЕШКЕ ПОСТПРОЦЕСИРАҢА $N X$ CAM: ГЕНЕРАТОР ПОДАТАКА О МАШИНИ НАСПРАМ ПОСТ-БИЛДЕР МОДУЛА}

\section{Срђан Живковић}

Замена или надоградња програмских пакета захтева детаљне анализе и тестирања. Ово је посебно важно код софтверских модула који су део производног процеса. Машинска обрада површина слободне форме захтева употребу петоосних глодалица. Постпроцесирање путање алата за ове машине захтева посебну анализу. Најважнији елемент постпроцесора је имплементирани инверзни кинематски солвер. Он мора прецизно да опише кинематику машине у производном погону. У Војнотехничком институту у Београду извршена су паралелна тестирања старог (GPM) и новог (MOM) постпроцесорског модула CAD/CAM система Siemens PLM NX. Комплетна анализа послата је групи за подршку произвођача софтвера где су инжењери подршке потврдили да се стари и нови постпроцесорски модули не понашају на идентичан начин. Овај рад детаљно описује ову анализу и објашњава начин решавања описаног проблема. 